\title{
Involvement of the IL-22/REG $1 \alpha$ axis in ulcerative colitis
}

\author{
Akira Sekikawa ${ }^{1}$, Hirokazu Fukui ${ }^{1}$, Katsumasa Suzuki ${ }^{1}$, Toyohiko Karibe ${ }^{2,1}$, Shigehiko Fujii ${ }^{1}$, Kazuhito Ichikawa ${ }^{1}$, \\ Shigeki Tomita ${ }^{1}$, Johji Imura ${ }^{1}$, Keiko Shiratori ${ }^{2}$, Tsutomu Chiba ${ }^{3}$ and Takahiro Fujimori ${ }^{1}$
}

The Regenerating gene (REG) l $\alpha$ protein, a trophic and/or anti-apoptotic factor, is important in the pathophysiology of gastrointestinal inflammation. Interleukin (IL)-22 is a recently identified cytokine that is suggested to have pivotal roles in inflammatory bowel diseases. We therefore investigated the involvement of the IL-22/REG $1 \alpha$ axis and examined the mechanism of regulation of REG $1 \alpha$ expression by IL-22 stimulation in ulcerative colitis (UC) mucosa. Expression of IL-22, IL-22 receptor 1 (IL-22R1), and REG I $\alpha$ in UC mucosa was analyzed by real-time RT-PCR and immunohistochemistry. The effects of IL-22 on REG I $\alpha$ protein expression were examined using a small-interfering RNA for STAT3, an MAPK inhibitor or a PI3K inhibitor. The element responsible for IL-22-induced REG l $\alpha$ promoter activation was determined by a promoter deletion and electrophoretic mobility shift assay. The expression of IL-22 was enhanced in infiltrating inflammatory cells, and that of IL-22R1 and REG I $\alpha$ was concurrently enhanced in the inflamed epithelium in UC mucosa. The levels of REG I $\alpha$ and IL-22 mRNA expression were strongly correlated, and the distributions of REG I $\alpha$ - and IL-22R1-positive epithelial cells were very similar. IL-22 simulation enhanced the expression of REG I $\alpha$ protein through STAT3 tyrosine phosphorylation in colon cancer cells. The IL-22-responsive element was located between -142 and -134 in the REG la promoter region. REG I $\alpha$ protein may have a pathophysiological role as a biological mediator for immune cell-derived IL-22 in the UC mucosa.

Laboratory Investigation (2010) 90, 496-505; doi:10.1038/labinvest.2009.147; published online 11 January 2010

KEYWORDS: REG; IL-22; IL-22 receptor; STAT3; ulcerative colitis

The Regenerating gene (REG), encoding a lectin-related protein, was originally isolated from rat regenerating pancreatic islet cells. ${ }^{1}$ Thereafter, its human homologue REG I $\alpha$ protein was suggested to be involved in the pathophysiology of gastrointestinal inflammation and its associated cancer. ${ }^{2-6}$ Indeed, we previously reported that REG I $\alpha$ protein behaves as a trophic and/or an anti-apoptotic factor in the development of colitis- or gastritis-associated cancer. ${ }^{5,6}$ To clarify the regulatory mechanism of REG I $\alpha$ gene expression, we initially screened major cytokines and showed that interleukin (IL)-6 and IFN $-\gamma$ are possible stimulators of REG I $\alpha$ gene expression under inflammatory conditions. ${ }^{5,6}$ However, the factors involved in ectopic expression of the REG $I \alpha$ gene in the inflammatory gastrointestinal mucosa are still unclear.

IL-22 was recently identified as a cytokine produced by activated $\mathrm{T}$ cells. ${ }^{7}$ Thereafter, accumulating data have indicated that not only IL-17-producing T (Th17) cells ${ }^{8-11}$ but also NK cells, ${ }^{12,13}$ dendritic cells, ${ }^{14}$ and lymphoid tissue-inducer cells ${ }^{15,16}$ are responsible for IL-22 production. Conversely, the receptors for IL-22 are known to consist of two chains: IL-22 receptor 1 (IL-22R1) and IL-10R2. ${ }^{17,18}$ Interestingly, IL-10R2 is expressed ubiquitously in various organs, whereas IL-22R1 is expressed specifically in pancreas, skin, kidney, liver, and colon, ${ }^{19,20}$ and moreover its expression is detectable in epithelial cells but not in immune cells in these organs. ${ }^{20}$ Thus, IL-22 may have pivotal roles in signaling from the immune system to epithelial cells under inflammatory conditions. Recently, it was suggested that IL-22 has a central role in the pathophysiology of inflammatory bowel disease. ${ }^{21,22}$ REG I $\alpha$, on the other hand, has been isolated in several microarray studies as a distinctly upregulated gene in the colonic epithelium in ulcerative colitis (UC). ${ }^{23,24}$ Interestingly, Zheng et al ${ }^{14}$ have recently reported that IL-22 mediates host defense against bacterial pathogens by inducing Reg family proteins in mice. In this study, therefore, we attempted to clarify whether the IL-22/REG I $\alpha$ axis is involved in the pathophysiology of UC and examined the regulatory mechanism of REG I $\alpha$ expression by IL-22 stimulation in UC mucosa.

\footnotetext{
${ }^{1}$ Department of Surgical and Molecular Pathology, Dokkyo University School of Medicine, Tochigi, Japan; ${ }^{2}$ Institution of Gastroenterology, Tokyo Women's Medical University, Tokyo, Japan and ${ }^{3}$ Department of Gastroenterology and Hepatology, Kyoto University Graduate School of Medicine, Kyoto, Japan

Correspondence: Dr H Fukui, MD, PhD, Department of Surgical and Molecular Pathology, Dokkyo University School of Medicine, 880 Kitakobayshi, Mibu, Shimotsuga, Tochigi 321-0293, Japan.

E-mail: h-fukui@dokkyomed.ac.jp

Received 27 May 2009; revised 2 November 2009; accepted 8 November 2009
} 


\section{MATERIALS AND METHODS}

\section{Tissue Specimens and Histological Examination}

Colon biopsy samples were obtained from the rectum by endoscopy from 60 patients with UC (32 men and 28 women; mean age 46.8 years, range 19-79) and 10 normal controls ( 6 men and 4 women; mean age 45.6 years, range 33-55) in 2003 and 2004 at Kyoto University Graduate School of Medicine and in 2006 and 2007 at Tokyo Women's Medical University. Tissue specimens were used for real-time RT-PCR and histological analyses. This work was carried out with the approval of the review board of Kyoto University Hospital and Tokyo Women's Medical University Hospital and the Dokkyo University Surgical Pathology Committee, and informed consent was obtained from all patients. The diagnosis of UC was based on clinical, endoscopic, and histological findings. ${ }^{25,26}$

\section{Real-Time RT-PCR}

Total RNA was isolated from the biopsy samples with Trizol reagent (Gibco-BRL, Rockville, MD, USA). Total RNA ( $4 \mu \mathrm{g})$ was reverse-transcribed using oligo-dT primer (Applied Biosystems, Branchburg, NJ, USA) and real-time RT-PCR was performed with the ABI PRISM 7000 Sequence Detection System (Applied Biosystems) as previously reported. ${ }^{27}$ The set of primers for $I L-22, I L-22 R 1, R E G I \alpha$, and glyceraldehydes-3-phosphate dehydrogenase $(G A P D H)$ were prepared as shown in Table 1. Real-time RT-PCR assays were carried out with 100 ng RNA equivalent cDNA, SYBR Green Master Mix (Applied Biosystems), and $500 \mathrm{nmol} / \mathrm{l}$ genespecific primers. The PCR cycling conditions were $50^{\circ} \mathrm{C}$ for $2 \mathrm{~min}, 95^{\circ} \mathrm{C}$ for $10 \mathrm{~min}$, followed by 40 cycles at $95^{\circ} \mathrm{C}$ for $15 \mathrm{~s}$, and $60^{\circ} \mathrm{C}$ for $60 \mathrm{~s}$. The intensity of the fluorescent dye was determined, and the expression levels of $I L-22, I L-22 R 1$, and $R E G I \alpha$ mRNA were normalized to GAPDH mRNA expression levels.

\section{Immunohistochemical Staining}

Immunohistochemical staining for IL-22, IL-22R1, and REG I $\alpha$ protein was performed with an Envision Kit (Dako, Kyoto, Japan) or an LSAB2 kit (Dako) as previously described, ${ }^{3}$ using anti-IL-22 antibody (1:200; Santa Cruz Biotechnology,

Table 1 Primers for real-time RT-PCR analysis

\begin{tabular}{lll}
\hline IL-22 & Forward & 5'-GCAGGCTTGACAAGTCCAACT-3' \\
& Reverse & 5'-GCCTCCTTAGCCAGCATGAA-3' \\
IL-22R1 & Forward & 5'-CTACATGTGCCGAGTGAAGA-3' \\
& Reverse & 5'-ACATATCTGTAGCTCAGGTA-3' \\
REG $\mid \alpha$ & Forward & 5'-CTAGAGGCAACTGGAAAATACATGTCT-3' \\
& Reverse & 5'-GTGGAGAGATGGTCCGGTाT-3' \\
GAPDH & Forward & 5'-GAGTCAACGGATTGGTCGT-3' \\
& Reverse & 5'-TTGATTTGGAGGGATCTCG-3' \\
\hline
\end{tabular}

Santa Cruz, CA, USA), anti-IL-22R1 antibody (1:25; Abcam, Cambridge, UK), and anti-human REG I $\alpha$ antibody (1:1000). Finally, the sections were incubated in 3,3'-diaminobenzide tetrahydrochloride with $0.05 \% \mathrm{H}_{2} \mathrm{O}_{2}$ for $5 \mathrm{~min}$, and then counterstained with Mayer's hematoxylin.

Immunohistochemical double staining was performed in UC tissues as previously reported. ${ }^{6}$ In brief, the sections were incubated with goat anti-IL-22 antibody (1:50), mouse antiCD3 antibody (1:200; Novocastra, Newcastle, UK), rabbit anti-IL-17 antibody (1:20; Santa Cruz Biotechnology), mouse anti-CD56 antibody (1:100; Novocastra) or mouse antiCD11c antibody (1:50; Novocastra) for $60 \mathrm{~min}$ at room temperature. Then, the sections were incubated with fluorescein isothiocyanate-conjugated anti-goat immunoglobulin (1:50; Dako, Glostrup, Denmark) and tetramethylrhodamine isothiocyanate-conjugated anti-mouse immunoglobulin (1:50; Dako) or tetramethylrhodamine isothiocyanate-conjugated anti-rabbit immunoglobulin (1:50; Dako) for $30 \mathrm{~min}$ at room temperature. After washing in phosphate-buffered saline, the sections were observed by confocal laser microscopy (DP70; Olympus, Tokyo, Japan).

\section{Cell Culture and Reagents}

Human colon cancer cell lines SW403 and LoVo cells were cultured in RPMI 1640 medium (Invitrogen, Grand Island, NY, USA) with $10 \%$ fetal bovine serum (Sigma, St Louis, MO, USA) in a humidified incubator at $37^{\circ} \mathrm{C}$ with an atmosphere of $5 \% \mathrm{CO}_{2}$. Human IL-22 was purchased from R\&D Systems (Minneapolis, MN, USA). MEK inhibitor PD98059 and PI3K-Akt inhibitor wortmannin were from Sigma. Anti-STAT3, anti-phospho-specific STAT3 (Tyr705), anti-Akt, anti-phospho-specific Akt (Ser473), anti-ERK, and anti-phospho-specific ERK antibodies were purchased from Cell Signaling Technology (Beverly, MA, USA). Anti- $\beta$-actin antibody was purchased from Sigma.

\section{Western Blot Analysis}

After treatment with or without reagents, cells were lysed in protein extraction buffer containing $20 \mathrm{mM}$ Tris- $\mathrm{HCl}(\mathrm{pH}$ 7.4), $150 \mathrm{mM} \mathrm{NaCl}, 2 \mathrm{mM}$ EDTA, $1 \%$ Nonidet P-40, $50 \mathrm{mM}$ $\mathrm{NaF}$, and $1 \times$ proteinase inhibitor (Complete Mini; Roche, Mannheim, Germany). Protein extract $(30 \mu \mathrm{g})$ was fractionated by SDS-polyacrylamide gel electrophoresis and transferred to a polyvinylidene difluoride membrane. The membrane was incubated with a primary antibody and then with a peroxidase-conjugated secondary antibody. Proteins were detected using an enhanced chemiluminescence system (Amersham Biosciences, Buckinghamshire, UK).

\section{RNA Interference}

Small-interfering RNA for human STAT3 (STAT3-siRNA) was obtained from Qiagen (Hilden, Germany). Cells were seeded in $6 \mathrm{~cm}$ dish (Iwaki, Funabashi, Japan) and maintained for $24 \mathrm{~h}$. Then, the cells were transfected with $25 \mathrm{nM}$ STAT3-siRNA or non-silencing siRNA (as a control) using 
the Oligofectamine reagent (Qiagen) according to the manufacturer's recommendation. After incubation for $48 \mathrm{~h}$, cells were washed with phosphate-buffered saline, and treated with IL-22 in serum-free medium. The protein was extracted from cells and subjected by western blot analysis or electrophoretic mobility shift assay (EMSA).

\section{Promoter Assay}

The fragment of the human REG I $\alpha$ promoter from -1195 to $+78(-1195 /+78)$ was cloned and inserted in the pGL3Basic vector (Promega, Madison, WI, USA) as previously reported. ${ }^{5}$ In brief, to obtain the deletion constructs, REG I $\alpha$ promoter fragments of $-811 /+78,-566 /+78,-339 /+78$, $-211 /+78,-153 /+78,-131 /+78$, and $-55 /+78$ were also cloned and inserted in the pGL3-Basic vector. Mutant plasmids were constructed to monitor the function of the sequences in the REG I $\alpha$ promoter corresponding to the potential IL-22 response element. Plasmids $-153 \mathrm{M} 1$ and $-153 \mathrm{M} 2$ were generated, in which the IL-22 response element was modified. The following oligonucleotides were used: for -153M1, 5' -CTCCCAGTGTGTGCCATACGAAGG3'; for -153M2, 5'-CTCCCAGTGCAGTAGGAAAAGG-3', the underlined sequences corresponding to modified regions. The oligonucleotide used for the opposite orientation was $5^{\prime}$ CCCGAAGATTTTAGATCTAGAGTGC- $3^{\prime}$ in all cases. After cloning and confirmation of the nucleotides by sequencing, the construct was named hREG I $\alpha$-Luc.

SW403 cells $\left(8 \times 10^{4}\right)$ or LoVo cells $\left(8 \times 10^{4}\right)$ were seeded $24 \mathrm{~h}$ before transfection in 12-well plate (Iwaki). Cells were co-transfected with $700 \mathrm{ng}$ of hREG I $\alpha$-Luc and $7 \mathrm{ng}$ of Renilla luciferase plasmid pRL-TK using Lipofectamine 2000 transfection reagent (Invitrogen). To inhibit the STAT3 signaling, we also transfected $25 \mathrm{nM}$ STAT3-siRNA. After $48 \mathrm{~h}$, the cells were stimulated with IL-22 for $24 \mathrm{~h}$ in the presence or absence of pretreatment of $20 \mu \mathrm{M}$ PD 98059 or $100 \mathrm{nM}$ wortmannin for $45 \mathrm{~min}$.

Luciferase assays were performed using the Dual Luciferase Reporter Assay system (Promega). Both firefly and Renilla luciferase activities were assayed by a luminometer (Lumat LB 9507; Berthold, Germany). The results obtained were normalized for Renilla luciferase activity and expressed relative to the activity of the untreated cell group.

\section{Electrophoretic Mobility Shift Assay}

DNA probes for EMSA were synthesized as oligonucleotides. The sequences of the individual oligonucleotides in the sense orientation were as follows: probe WT, $5^{\prime}$-AGTGTGTGCCG GGAAAAGG- $3^{\prime}$ corresponding to nucleotides -148 to -130 of the REG I $\alpha$ promoter gene; probe M1, $5^{\prime}$-AGTGTGTGCC ATACGAAGG- $3^{\prime}$; probe M2, $5^{\prime}$-AGTGTGCAGTAGGAAAA GG-3'. SW403 cells were pretreated with or without STAT3siRNA or $20 \mu \mathrm{M}$ PD 98059, followed by stimulation with IL$22(10 \mathrm{ng} / \mathrm{ml})$ for $30 \mathrm{~min}$, and nuclear protein was extracted as previously described. ${ }^{28}$ EMSA was carried out with a Gel Shift Assay System (Promega) in accordance with the manufacturer's recommendation. Briefly, the probes were generated by $5^{\prime}$-end labeling with $\left[\gamma^{-}{ }^{32} \mathrm{P}\right]$ ATP (Amersham Biosciences) and T4 polynucleotide kinase (Promega). The nuclear protein $(10 \mu \mathrm{g})$ was preincubated in a final volume of $9 \mu \mathrm{l}$ of buffer containing $10 \mathrm{mM}$ Tris- $\mathrm{HCl}(\mathrm{pH} 7.5), 1 \mathrm{mM}$ $\mathrm{MgCl}_{2}, 50 \mathrm{mM} \mathrm{NaCl}, 0.5 \mathrm{mM}$ EDTA, $4 \%$ glycerol, $0.5 \mathrm{mM}$ DTT, and $0.5 \mathrm{mg}$ of poly $(\mathrm{dl}-\mathrm{dC})$ for $10 \mathrm{~min}$ at room temperature. Then, the ${ }^{32} \mathrm{P}$-labeled probe was added to the mixture, followed by incubation for $20 \mathrm{~min}$ at room temperature. For the supershift assay, $2 \mu \mathrm{g}$ of antibody was added to the preincubation mixture, and additionally incubated for $15 \mathrm{~min}$. The protein-DNA complexes were electrophoresed on a $6 \%$ acrylamide gel, and the gels were dried before autoradiography.

\section{Statistical Analysis}

All values for relative luciferase activity and real-time RT-PCR were expressed as the mean \pm s.e.m. These data were analyzed using an unpaired two-tailed $t$-test. The relationship between REG $I \alpha, I L-22$, and $I L-22 R 1$ mRNA levels was assessed by linear regression analysis. $P$-values of less than 0.05 were considered to indicate statistical significance.

\section{RESULTS \\ Expression of IL-22, IL-22R1, and REG I $\alpha$ mRNA is Enhanced in UC Mucosa}

To investigate whether the IL-22/REG I $\alpha$ axis is involved in the pathophysiology of inflammatory bowel disease, we examined the expression of $I L-22, I L-22 R 1$, and REG $I \alpha$ mRNA in UC tissues by real-time RT-PCR analysis. Both $I L-22$ and REG I $\alpha$ expression were significantly greater in UC tissues than in normal colonic tissue (Figure 1). Moreover, the level of $I L-22 R 1 \mathrm{mRNA}$ was significantly greater in UC tissue than in normal colonic tissue. We then analyzed the relationship between $I L-22, I L-22 R 1$, and $R E G I \alpha$ expression in UC tissues. The expression of REG I $\alpha$ in UC tissues was significantly correlated with that of $I L-22$ and $I L-22 R 1$ (Figure 2a). The expression of $I L-22 R 1$ in UC tissues was also correlated with that of $I L-22$.

\section{Localization of IL-22, IL-22R1, and REG I $\alpha$ Protein Expression in Normal Colonic and UC Mucosa}

In normal colonic mucosa, immunoreactivity for IL-22 was hardly detected even in lymphocytes (Figure 3a). As shown in Figure $3 \mathrm{~b}$ and c, IL-22R 1 and REG I $\alpha$ were coexpressed in a few epithelial cells in the basal portion of crypts (arrows). In UC mucosa, the numbers of IL-22-positive lymphocytes and IL-22R1-positive crypt cells were increased (Figure 3d and e). Both the number of REG I $\alpha$-positive crypt cells and the signal intensity in each cell were also increased in UC mucosa (Figure 3f).

To clarify which types of cells produce IL-22 in UC mucosa, we moreover carried out double immunostainings for IL-22 and several cell markers. CD3-positive T cells were observed throughout lamina propria, whereas IL-22-positive 

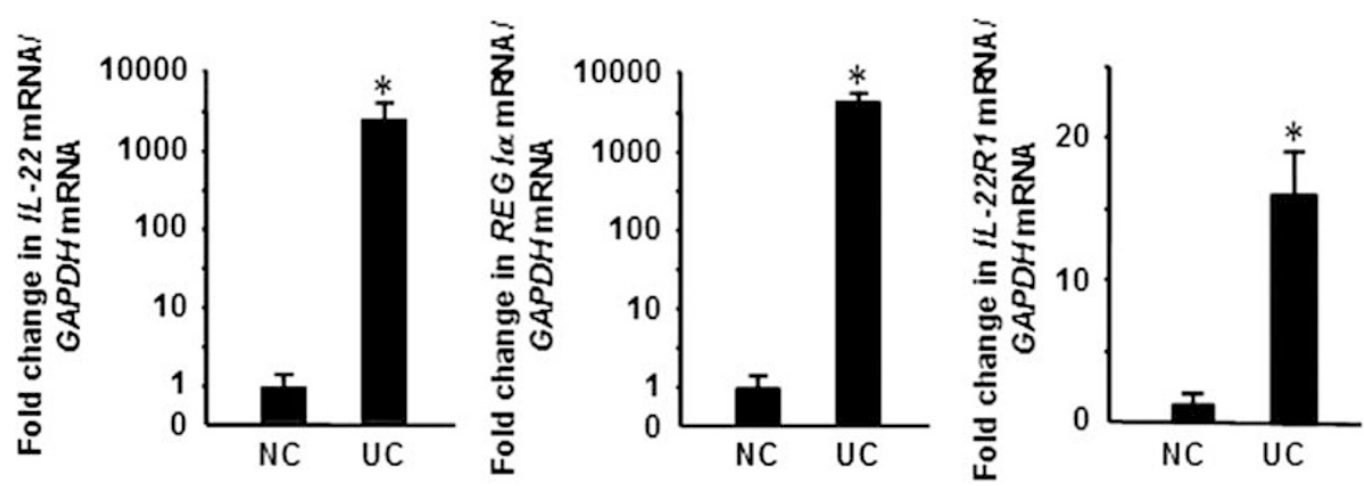

Figure $1 \mathrm{LL}-22, I L-22 R 1$, and $R E G$ I $\alpha$ mRNA expression in normal colon (NC) and ulcerative colitis (UC) tissues. All results are expressed as fold change in IL-22, IL-22R1, or REG I $\alpha / G A P D H$ mRNA ratio relative to the normal colon group. ${ }^{\star} P<0.05$ vs normal colon group.
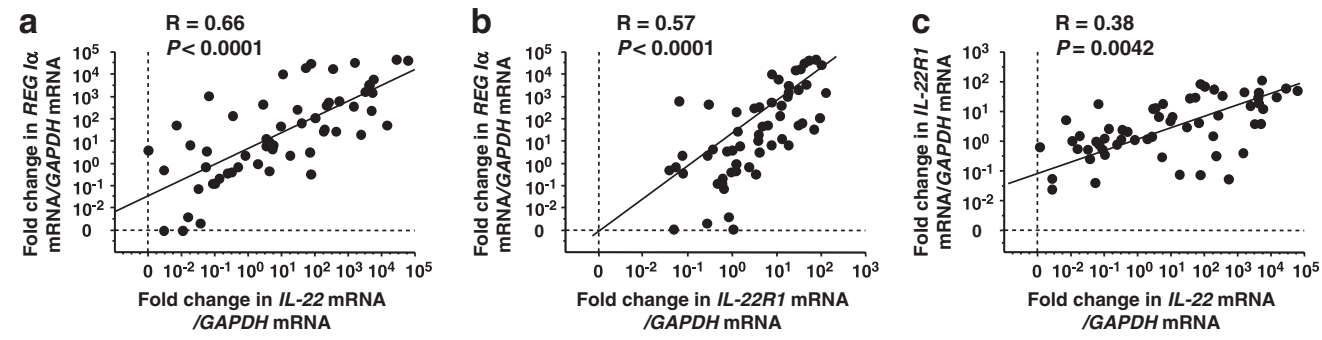

Figure 2 Correlation between $I L-22$ and $R E G I \alpha(\mathbf{a}), I L-22 R 1$ and $R E G I \alpha(\mathbf{b}), I L-22$ and $I L-22 R 1$ (c) mRNA expression levels in UC tissues. All results are expressed as fold change in $I L-22, I L-22 R 1$, or REG I $\alpha / G A P D H$ mRNA ratio relative to the normal colon group.
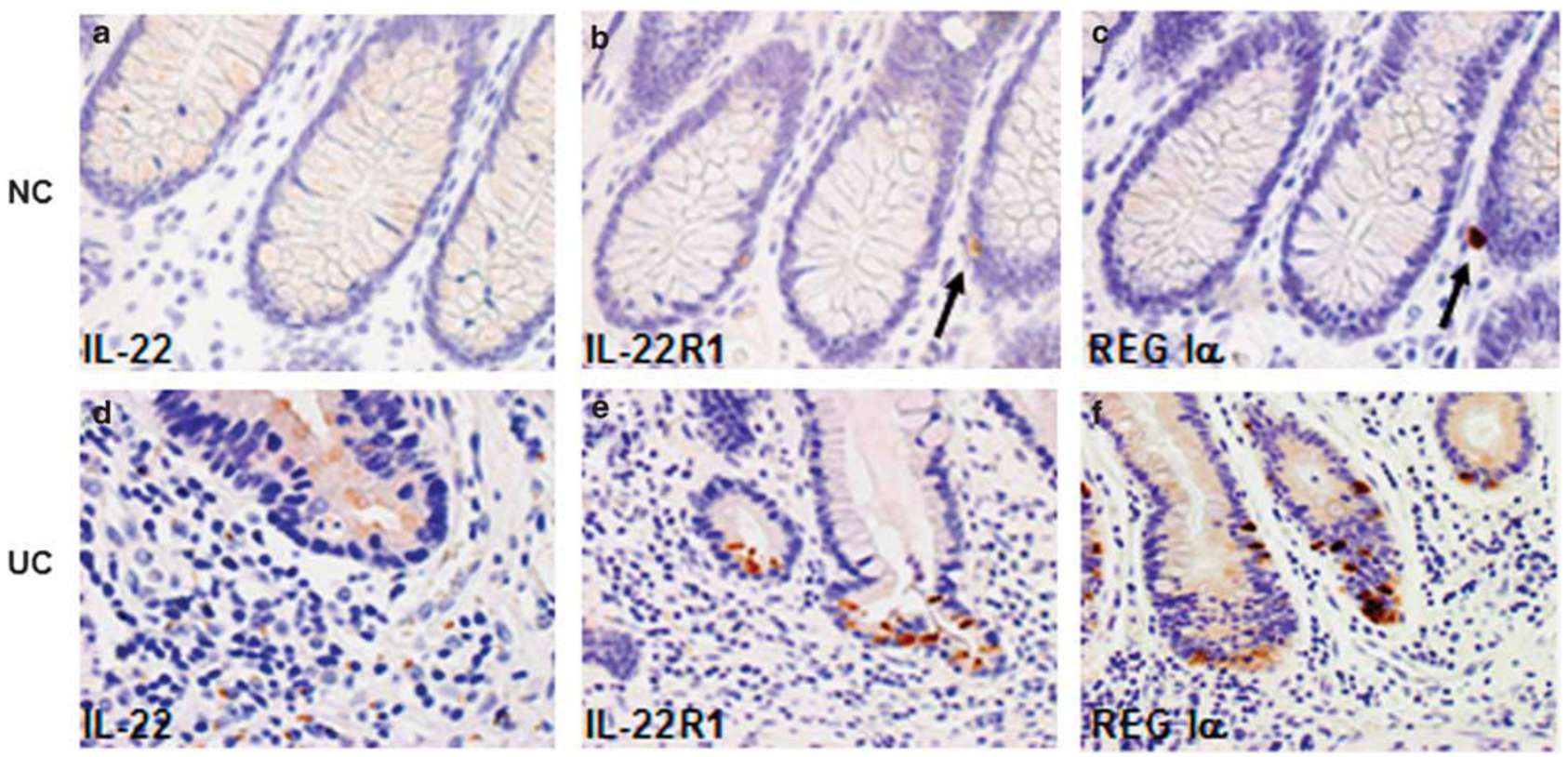

Figure 3 Immunostaining of IL-22, IL-22R1, and REG I $\alpha$ in normal colon (NC) (a-c) and UC mucosa (d--f). Arrows indicate the epithelial cell co-expressing IL-22R1 and REG I $\alpha$.

and IL-17-positive cells were mainly found in the lamina propria near muscularis mucosae in UC tissues (Figure 4a and b). Some IL-22-positive cells coexpressed CD3 or IL-17 but others expressed IL-22 alone, suggesting that not only IL17-producing $\mathrm{T}$ cells but also other types of cells are possible to produce IL-22 in UC mucosa. Furthermore, we observed 

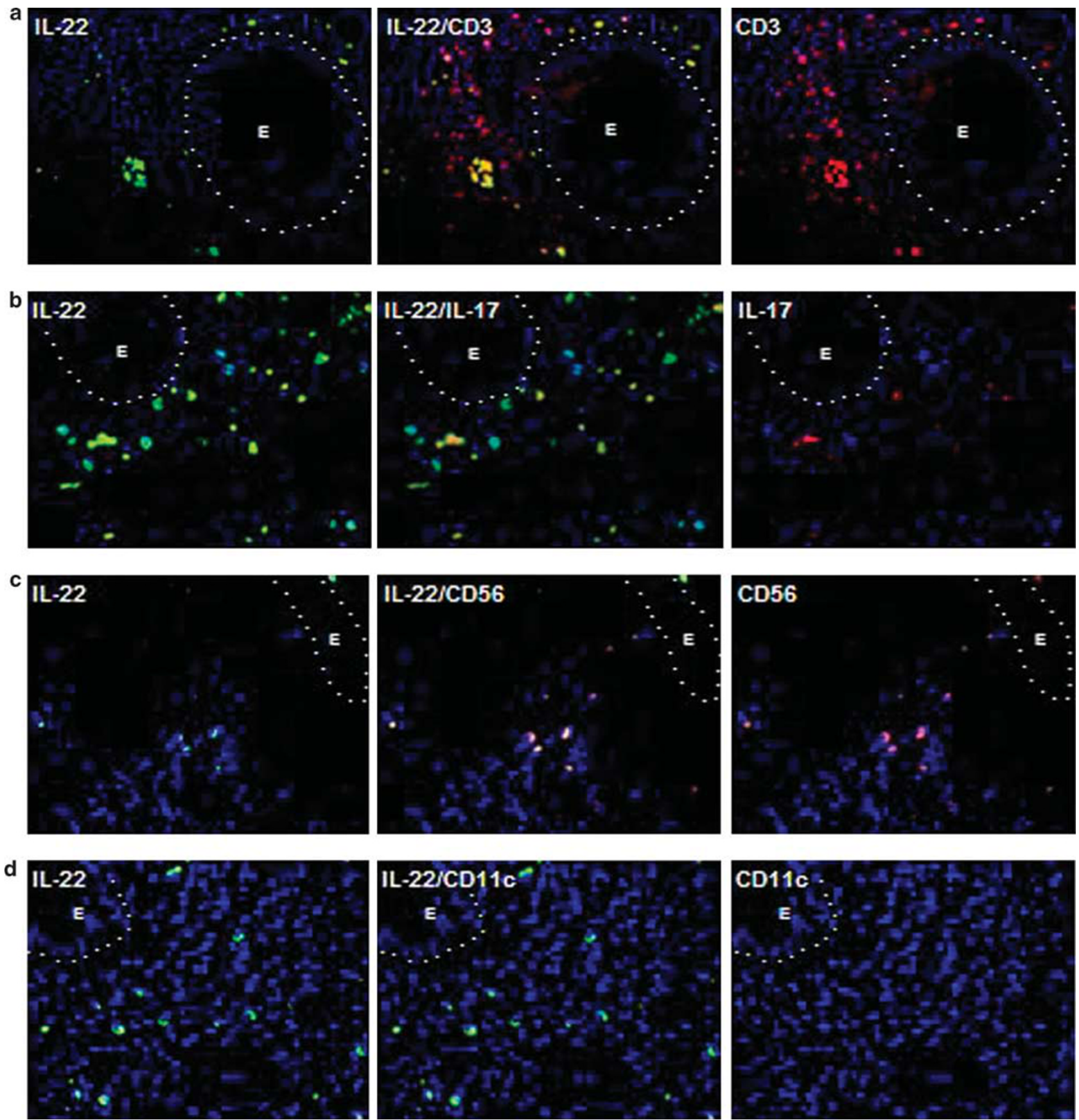

Figure 4 Double immunostaining of IL-22 and CD3 (a), IL-17 (b), CD56 (c), or CD11c (d) in UC mucosa (left, IL-22; right, other markers; middle, merged image). IL-22- and IL-17-positive cells were mainly observed in the lamina propria near muscularis mucosa in UC tissues (green signal in A and red signal in B, respectively). Some IL-22-positive cells co-expressed CD3 or IL-17 there (yellow signal in A and B, respectively). (c) Inflammatory cells partially co-expressed IL-22 and CD56 in the lamina propria near muscularis mucosae in UC tissue. (d) IL-22-positive cells were hardly positive for CD11C in such portion. Nuclei were stained with DAPI (blue signal) using ProLong Gold and SlowFade Reagents (Invitrogen). E, epithelial cell structure.

that inflammatory cells partially coexpressed IL-22 and CD56 in the lamina propria near muscularis mucosae in UC tissues (Figure 4c), suggesting that NK cells are in part responsible for IL-22 production in UC mucosa. Conversely, IL-22-positive cells were hardly positive for CD11c in such portion (Figure 4d), although CD11c-positive cells were observed mainly in the upper part of lamina propria in UC mucosa.

\section{IL-22 Enhances REG I $\alpha$ Promoter Activity and Protein Expression in Colon Cancer Cells}

The effect of IL-22 stimulation on REG I $\alpha$ promoter activity was examined in two colon cancer cell lines by luciferase reporter assay. In both SW403 and LoVo cells, REG I $\alpha$ promoter activity was enhanced by IL-22 stimulation in a dose-dependent manner $(0-100 \mathrm{ng} / \mathrm{ml})$ (Figure $5 \mathrm{a}$ and $\mathrm{b}$ ). 

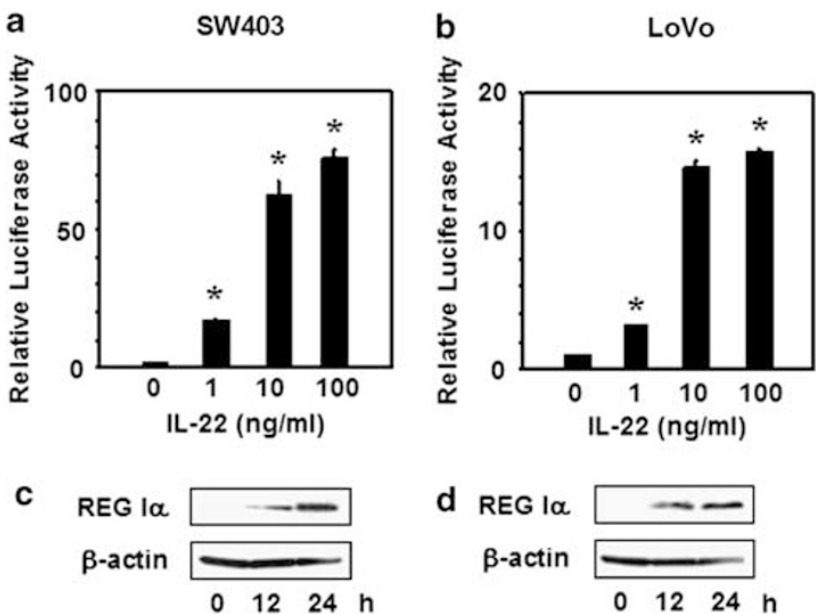

Figure 5 Effects of IL-22 on REG $1 \alpha$ promoter activity (a and $\mathbf{b})$ and REG $1 \alpha$ protein expression (c and d) in colon cancer cells. SW403 $\left(\mathbf{a}: 8 \times 10^{4}\right)$ and LoVo cells $\left(\mathbf{b}: 8 \times 10^{4}\right)$ were seeded $24 \mathrm{~h}$ before transfection in 12-well plates. Cells were co-transfected with hREG $1 \alpha(-1195 /+78)$-Luc construct and Renilla luciferase plasmid pRL-TK. After $48 \mathrm{~h}$, the cells were stimulated with various doses of IL-22 for $24 \mathrm{~h}$. Then luciferase activity was measured and normalized to Renilla luciferase activity. The results are expressed as the proportion of the activity relative to the untreated cell group and represented as the mean \pm s.e.m. of four samples. ${ }^{*} P<0.01$ vs the untreated cell group. SW403 $\left(\mathbf{c}: 1 \times 10^{6}\right)$ and LoVo cells $\left(\right.$ d: $\left.1 \times 10^{6}\right)$ were cultured in $6 \mathrm{~cm}$ dishes for $24 \mathrm{~h}$. After the cells had been treated with IL-22 $(10 \mathrm{ng} / \mathrm{ml})$ for 12 and $24 \mathrm{~h}$, extracted protein was analyzed using western blotting.

Western blot analysis also showed that the expression of REG I $\alpha$ protein was enhanced in SW403 and LoVo cells at 12 and $24 \mathrm{~h}$ after IL-22 stimulation (Figure $5 \mathrm{c}$ and $\mathrm{d}$ ).

\section{IL-22 Induces Phosphorylation of ERK, STAT3, and AKT in Colon Cancer Cells}

We next examined the activation of three major types of intracellular signaling possibly linked to IL-22 stimulation in colon cancer cells. IL-22 strongly activated STAT3 phosphorylation and moderately activated ERK phosphorylation from 5 min after stimulation in both SW403 and LoVo cells. IL-22 stimulation induced Akt phosphorylation in SW403 cells, but did not affect the phosphorylation of Akt in LoVo cells (Figure 6).

\section{IL-22 Enhances REG I $\alpha$ Protein Expression in Colon Cancer Cells by a STAT3-Dependent Mechanism}

Using an siRNA system for STAT3, we examined the contribution of STAT3 signaling to IL-22-induced REG I $\alpha$ expression in colon cancer cells. As shown in Figure 7a and b, the increased level of phospho-specific STAT3 in IL-22-treated colon cancer cells was decreased by the treatment with STAT3-siRNA in both SW403 and LoVo cells. Similarly, the increased level of REG I $\alpha$ promoter activity in IL-22-treated colon cancer cells was abolished by treatment with STAT3siRNA (Figure 7c and d). Moreover, inhibition of STAT3 signaling with STAT3-siRNA clearly reduced the increase of
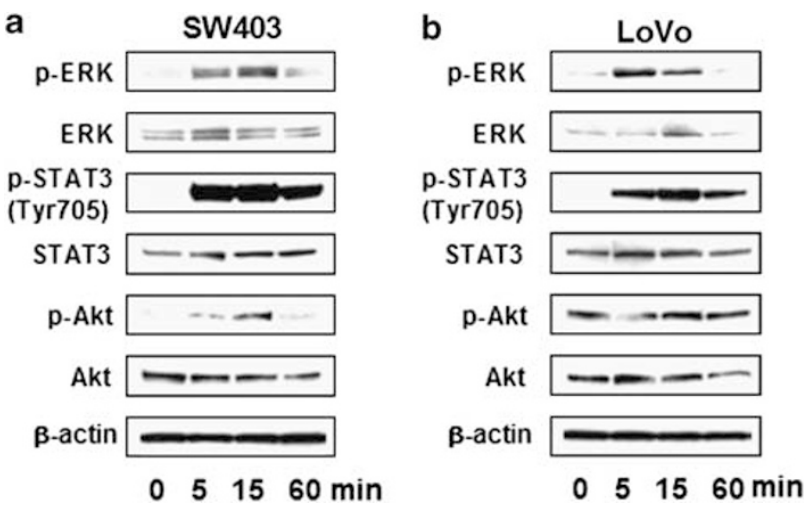

Figure 6 Effects of IL-22 on phosphorylation of ERK, STAT3, and Akt in colon cancer cells. SW403 $\left(\mathbf{a}: 1 \times 10^{6}\right)$ and LoVo cells $\left(\mathbf{b}: 1 \times 10^{6}\right)$ were cultured in $6 \mathrm{~cm}$ dishes for $24 \mathrm{~h}$. After the cells had been treated with IL-22 $(10 \mathrm{ng} / \mathrm{ml})$ for the indicated time, extracted protein was analyzed using western blotting.
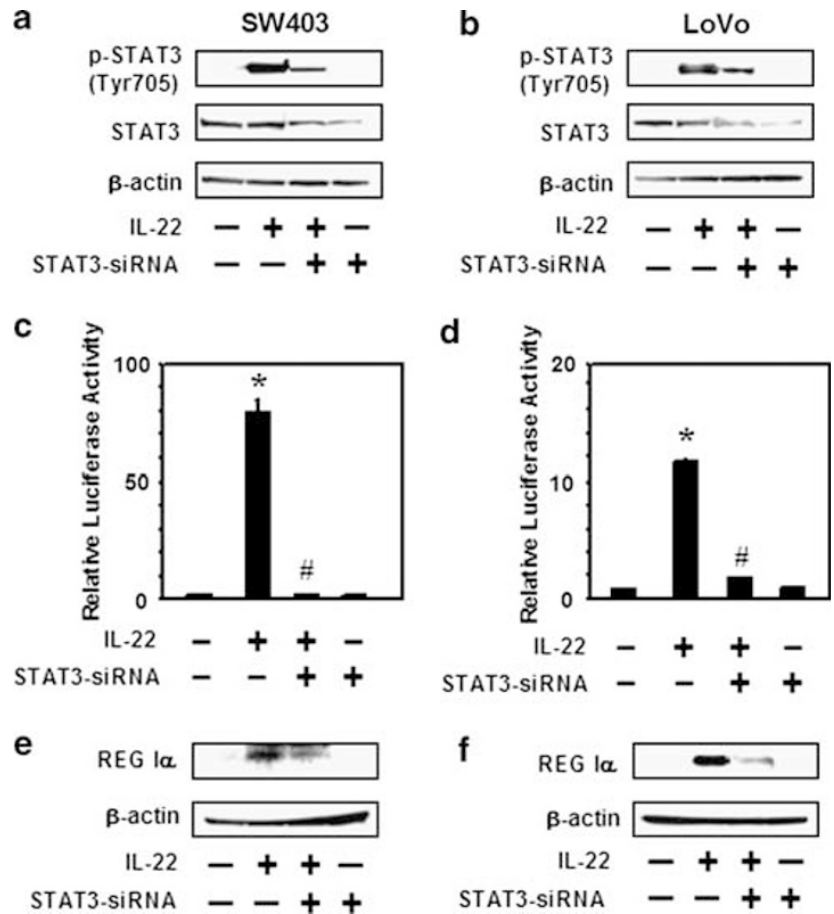

Figure 7 Effects of STAT3 siRNA treatment on IL-22-induced STAT3 phosphorylation (a and b), REG l $\alpha$ promoter activity (c and $\mathbf{d}$ ), and REG $1 \alpha$ protein expression (e and $\mathbf{f}$ ) in colon cancer cells. SW403 (a and e: $1 \times 10^{6}$ ) and LoVo cells (b and $\mathbf{f}: 1 \times 10^{6}$ ) were transfected with STAT3 siRNA (or non-silencing siRNA as a control) for $48 \mathrm{~h}$. After transfection, the cells were stimulated with IL-22 $(10 \mathrm{ng} / \mathrm{ml})$ for $15 \mathrm{~min}$ to evaluate STAT3 phosphorylation (a and $\mathbf{b}$ ), and for $24 \mathrm{~h}$ to evaluate REG $1 \alpha$ protein expression (e and $\mathbf{f}$ ). Extracted protein was analyzed using western blotting. SW403 (c: $\left.8 \times 10^{4}\right)$ and LoVo cells $\left(\mathbf{d}: 8 \times 10^{4}\right)$ were co-transfected with hREG $1 \alpha(-1195 /+78)$-Luc construct, Renilla luciferase plasmid pRL-TK, and STAT3 siRNA (or non-silencing siRNA as a control) for $48 \mathrm{~h}$. After transfection, cells were stimulated with IL-22 $(10 \mathrm{ng} / \mathrm{ml})$ for $24 \mathrm{~h}$ and luciferase activity was measured. The results are expressed as the proportion of the activity of the untreated cell group and represented as the mean \pm s.e.m. of four samples. ${ }^{*} P<0.01$ vs the untreated cell group, ${ }^{\#} P<0.01$ vs IL-22-treated cell group. 
a

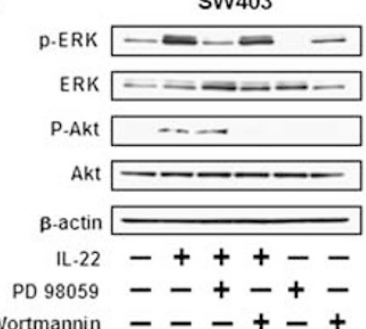

c

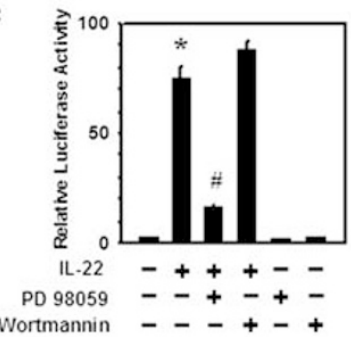

e

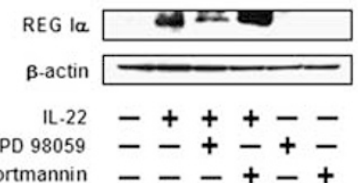

b

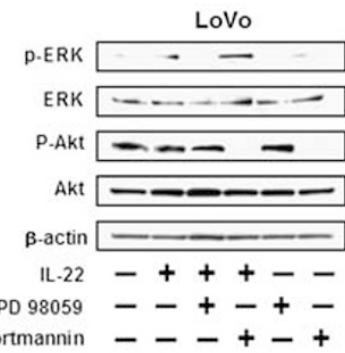

d
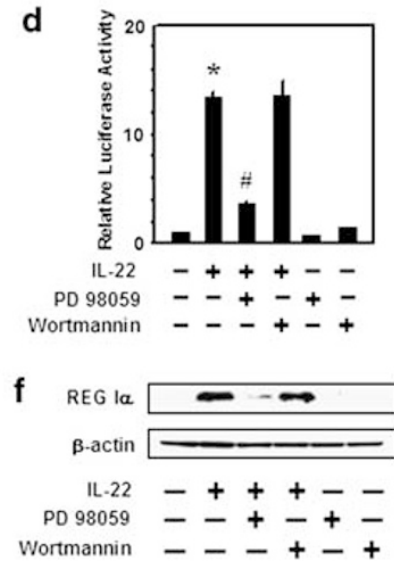

Figure 8 Effects of MEK inhibitor or PI3K-Akt inhibitor on IL-22-induced ERK phosphorylation, Akt phosphorylation (a and b), REG l $\alpha$ promoter activity (c and $\mathbf{d}$ ), and REG $1 \alpha$ protein expression (e and $\mathbf{f}$ ) in colon cancer cells. SW403 (a and e: $1 \times 10^{6}$ ) and LoVo cells (b and f: $1 \times 10^{6}$ ) were pretreated with $20 \mu \mathrm{M}$ PD98059 or $100 \mathrm{nM}$ wortmannin for $45 \mathrm{~min}$ and then stimulated with IL-22 $(10 \mathrm{ng} / \mathrm{ml})$ for $15 \mathrm{~min}$ to detect ERK and Akt phosphorylation (a and $\mathbf{b}$ ), and for $24 \mathrm{~h}$ to detect REG $\mathrm{l} \alpha$ protein expression $\left(\right.$ e and f). SW403 $\left(\right.$ c: $\left.8 \times 10^{4}\right)$ and LoVo cells $\left(\mathbf{d}: 8 \times 10^{4}\right)$ were co-transfected with hREG $1 \alpha(-1195 /+78)$-Luc construct and Renilla luciferase plasmid pRL-TK for $48 \mathrm{~h}$. After transfection, cells were treated with $20 \mu \mathrm{M}$ PD98059 or $100 \mathrm{nM}$ wortmannin for $45 \mathrm{~min}$, stimulated with IL-22 $(10 \mathrm{ng} / \mathrm{ml})$ for $24 \mathrm{~h}$, and luciferase activity was measured. The results are expressed as the proportion of the activity of the untreated cell group and represented as the mean \pm s.e.m. of four samples. ${ }^{*} P<0.01$ vs the untreated cell group, ${ }^{\#} P<0.01$ vs IL-22-treated cell group.

REG I $\alpha$ protein expression by IL-22 in both colon cancer cells (Figure $7 \mathrm{e}$ and $\mathrm{f}$ ).

\section{MAPK Signaling is Partially Responsible for IL-22-Induced REG I $\alpha$ Protein Expression in Colon Cancer Cells}

We examined whether MAPK or PI3K-Akt signaling is involved in IL-22-induced REG I $\alpha$ expression in colon cancer cells. The increased level of phospho-specific ERK in IL-22treated cells was inhibited by concomitant administration of the MEK inhibitor PD 98059 (Figure 8a and b). In addition, the increased level of phospho-specific Akt in SW403 cells treated with IL-22 was decreased by treatment with the PI3K inhibitor wortmannin (Figure 8a). In the case of LoVo cells, the basic level of phospho-specific Akt was high, and IL-22 stimulation had no additional effect on the increase in the phospho-specific Akt level, suggesting that Akt may be constitutively activated in LoVo cells. However, the treatment with wortmannin $(500 \mathrm{nM})$ abolished Akt activation in LoVo cells. We then examined whether inhibition of MAPK signaling or PI3K-Akt signaling affected REG $I \alpha$ promoter activity and protein expression. Treatment with PD 98059 partially attenuated IL-22-induced REG I $\alpha$ promoter activity, whereas treatment with wortmannin did not affect $R E G I \alpha$ promoter activity in both colon cancer cells (Figure $8 \mathrm{c}$ and d). Consistent with these data, treatment with PD 98059 partially decreased IL-22-induced REG I $\alpha$ protein expression in colon cancer cells. However, wortmannin did not affect REG I $\alpha$ protein expression in either SW403 or LoVo cells (Figure 8e and $\mathrm{f}$ ). These findings suggest that IL-22 stimulation can activate both MAPK and Akt signaling in those cells, and moreover that MAPK but not Akt signaling is in part linked to REG I $\alpha$ expression in colon cancer cells.

\section{Determination of the Element Responsive to IL-22-Induced REG l $\alpha$ Promoter Activation in Colon Cancer Cells}

The element responsive to IL-22-induced REG I $\alpha$ promoter activation was determined in a series of promoter deletion assays. When deletion of the $5^{\prime} R E G I \alpha$ promoter gene was extended from position -1195 to -153 , a significant increase of luciferase activity was sustained. However, the luciferase activity returned to the control level when the promoter region was additionally deleted up to -131 (Figure 9a). These findings suggest that the promoter region between -153 and -131 is critical for REG $I \alpha$ promoter activation by IL-22 stimulation. To identify the precise consensus sequences for IL-22-induced REG I $\alpha$ promoter activation, we used mutant constructs (Figure 9b). As shown in Figure 9c, neither $-153 \mathrm{M} 1$ nor $-153 \mathrm{M} 2$ responded to IL-22 stimulation, suggesting that the element located between position -142 and -134 (TGCCGGGAA) is responsible for IL-22-induced REG I $\alpha$ promoter activation. The binding of the nuclear extract to candidate nucleotides for the IL-22-responsive element was examined by EMSA. IL-22 enhanced the binding of nuclear extracts to the probe, and this enhanced activity was reduced by inhibition of STAT3 signaling with the siRNA system. However, inhibition of MAPK signaling did not affect the binding activity (Figure 9d). Moreover, disruption of the responsive element resulted in complete loss of the binding activity (Figure 9e). Finally, supershift analysis clearly revealed a supershifted band when the responsive elementbinding nuclear factors were treated with anti-STAT3 antibody, suggesting that IL-22-induced STAT3 proteins bind to the responsive element in the REG I $\alpha$ promoter region (Figure 9f).

\section{DISCUSSION}

Although the pathogenesis of UC is still unclear, accumulating evidence suggests that active cross talk mediated by cytokines between immune and nonimmune cells is importantly involved in the amelioration and/or exacerbation of inflammation in UC mucosa. ${ }^{29,30}$ Interestingly, IL-22 is thought to be produced by immune cells such as Th17, NK, 


\section{a}

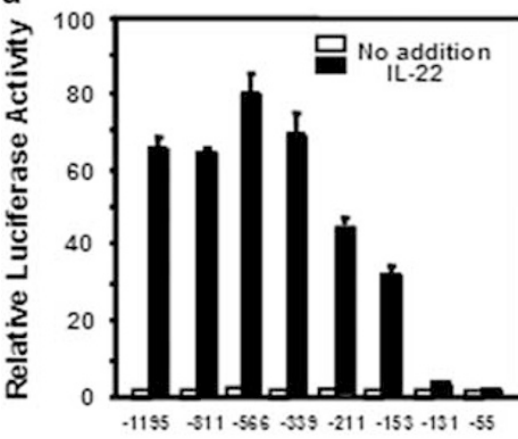

b

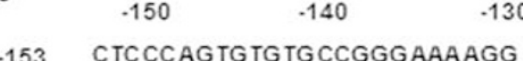

-153M1 •...... TGCCATACG $\cdots \cdots$

$-153 \mathrm{M} 2 \cdots \cdots \cdots \cdots \cdot$ CAGTAGGAA $\cdots \cdots$

c

d
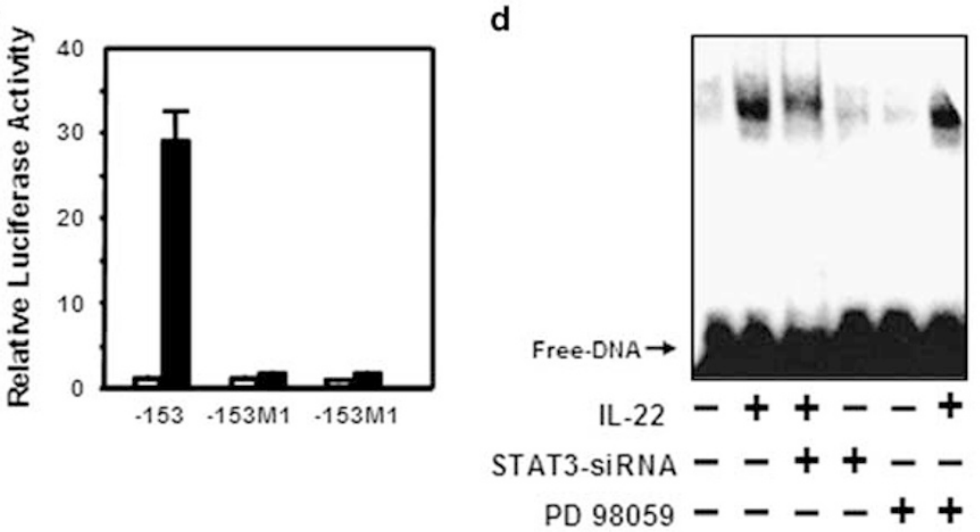

e

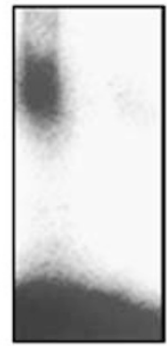

f

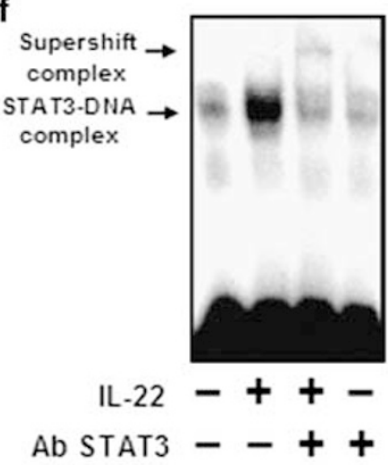

Labeled probe (WT) +-

Labeled probe (M1) - +

Labeled probe (M2) $--\mathbf{t}$

Ab STAT3 $-\boldsymbol{+}+$

$\mathrm{IL} \cdot 22(10 \mathrm{ng} / \mathrm{ml})$

Figure 9 Identification of the element responsive to IL-22-induced REG I $\alpha$ promoter activation. (a) Deletion analysis of the REG I $\alpha$ promoter. Constructs listed on the ordinate are numbered according to their $5^{\prime}$ terminus in the REG l $\alpha$ promoter. SW 403 cells were transfected with the corresponding plasmids for $48 \mathrm{~h}$ and then stimulated with IL-22 (10 ng/ml). Relative luciferase activity in extracts from each cell group was measured. In all of the constructs except for -131 and -55, significant increases in luciferase activity by IL-22 stimulation were retained $(P<0.01)$. (b) Alignment of the REG l $\alpha$ gene promoter. Nucleotide substitutions in the cis-element are indicated by underlining. Dots indicate residues that are identical to the REG l $\alpha$ gene promoter. (c) Effects of site-directed mutagenesis of the ciselement within the REG la promoter. Relative luciferase activity was measured by using mutant plasmids. Significant increase in luciferase activity was retained in the -153 plasmid but not in $-153 \mathrm{M} 1$ or $-153 \mathrm{M} 2(P<0.01)$. The binding activity of nuclear extracts to the responsive element for IL-22-induced $R E G$ l $\alpha$ promoter activation was analyzed by EMSA. (d) Nuclear extracts were obtained from SW403 cells stimulated with IL-22 (10 ng/ml) for 30 min in the presence or absence of pretreatment with STAT3-siRNA or $20 \mu \mathrm{M}$ PD 98059. The nuclear proteins were incubated with a ${ }^{32} \mathrm{P}$-labeled WT probe including the responsive element for IL22-induced REG I $\alpha$ promoter activation for $20 \mathrm{~min}$. (e) The nuclear extracts from SW403 cells stimulated with IL-22 (10 ng/ml) were incubated with ${ }^{32} \mathrm{P}$-labeled WT, M1, or M2 probe for $20 \mathrm{~min}$. (f) Nuclear proteins were obtained from SW403 cells stimulated with IL-22 (10 ng/ml) and then incubated with STAT3 antibodies for $15 \mathrm{~min}$, followed by further incubation with a ${ }^{32}$ P-labeled WT probe for $20 \mathrm{~min}$. Then the position of the STAT3-DNA complex and supershifted complex was examined. All results in $\mathbf{a}$ and $\mathbf{c}$ are represented as the mean \pm s.e.m. of four samples.

dendritic, and lymphoid tissue-inducer cells, whereas its receptor IL-22R1 is present only in nonimmune cells such as epithelial, endothelial cells, and fibroblasts. ${ }^{20,21}$ Thus, IL-22 may be a specific mediator of signals from inflammatory cells to nonimmune cells in the UC mucosa. Of note, we observed in this study that the number IL-22-positive immune cell was increased in the lamina propria of UC mucosa. Although it is difficult to characterize IL-22-positive immune cells, we 
speculate immunohistochemically that Th17 and NK cells may be responsible for IL-22 production in UC mucosa. Conversely, we also found that the expression of IL-22R1 was enhanced in colonic epithelial cells in UC mucosa. Accordingly, it is likely that IL-22 signaling from immune cells is important in the biological behavior of colonic epithelial cells in UC mucosa.

IL-22 has been recently reported to stimulate colonic epithelial cell lines to produce regulatory molecules (IL-10, STAT3), ${ }^{31,32}$ anti-bacterial peptides ( $\beta$-defensin, calgranulins), ${ }^{33,34}$ and mucin (MUC1, $-3,-10$, and -13$) .{ }^{35,36}$ In this study, we examined whether IL-22 stimulation is responsible for REG $\mathrm{I} \alpha$ overexpression in the colonic epithelium in UC mucosa, because in several gene tip analyses REG I $\alpha$ has been proven to be a distinctly upregulated gene in the colonic epithelium of patients with UC. ${ }^{23,24}$ Moreover, we found using microarray analysis that $R E G I \alpha$ is also a novel upregulated gene in a colon cancer cell line stimulated with IL-22 (data not shown). First, the expression of REG I $\alpha$ was strongly correlated with that of $I L-22$ in UC mucosal tissues. Second, the distributions of REG I $\alpha$ - and IL-22R1-positive epithelial cells were similar, and the infiltration of IL-22-positive inflammatory cells was increased around such colonic epithelial cells. Third, in vitro studies revealed that IL-22 stimulation indeed enhances REG $\mathrm{I} \alpha$ expression in colon cancer cell lines. Conversely, it was interesting that REG I $\alpha$ and IL-22R1 were coexpressed in a few crypt cells in normal colonic glands, although the biological significance of this was unclear. Together, it appears reasonable to speculate that IL-22 stimulation is responsible for REG $I \alpha$ overexpression in the colonic epithelium of UC mucosa.

In this study, we also examined the mechanism by which IL-22 signaling is linked to the enhancement of REG I $\alpha$ expression in colonic epithelial cells. A series of in vitro studies clearly showed that IL-22 stimulation enhances REG I $\alpha$ expression through STAT3 tyrosine phosphorylation and that the STAT3-binding site lies between -142 and -134 in the REG I $\alpha$ promoter region. Alternatively, we also found that ERK signaling is in part associated with IL-22-induced REG I $\alpha$ expression. Interestingly, it has been reported that ERK activation promotes STAT3 serine phosphorylation and upregulates its target protein expression in a few cell lines. ${ }^{37,38}$ Therefore, we stimulated a colon cancer cell line with IL-22, and subsequently found that IL-22 stimulation is possible to enhance REG I $\alpha$ expression by ERK-dependent STAT3 serine phosphorylation in such cells (Supplementary Figure 1). Although the whole network of IL-22-induced intracellular signaling leading to REG $\mathrm{I} \alpha$ expression still remains to be elucidated, it is certain that STAT3 signaling is crucial for IL-22-induced REG I $\alpha$ expression (Supplementary Figure 2).

What pathophysiological roles, then, does IL-22 has in the UC mucosa? At present, although we have no obvious answers in patients with UC, but a colitis-model of UC has recently revealed that IL-22 ameliorates intestinal inflammation by enhancing the production of membranebound mucins (MUC-1, -3, and -13) from colonic epithelium. ${ }^{35}$ Zenewicz et al $^{12}$ have also reported recently that IL-22 derived from $\mathrm{T}$ and $\mathrm{NK}$ cells protects mice from inflammatory bowel disease. Moreover, several studies have emphasized that IL-22 mediates host defense against bacterial pathogens ${ }^{14,39}$ and furthermore promotes wound healing by exerting cell proliferative and/or anti-apoptotic effects. ${ }^{33,40}$ Thus, IL-22 may be involved in the protection of colonic mucosa from inflammation, or in recovery from colonic mucosal injury. Interestingly, Zheng et al $^{14}$ have very recently reported that Reg family proteins mediate the antibacterial effect of IL-22 in murine experimental colitis. Conversely, along with others, we have suggested that REG family proteins are importantly involved in the regeneration of gastrointestinal mucosa by exerting mitogenic and/or antiapoptotic effects. ${ }^{4,6,27,41}$ Accordingly, together with our present data, it is tempting to speculate that REG family proteins are pivotal targets for IL-22 in protecting the colonic mucosa from inflammation-associated injury, although further studies will be needed to test this hypothesis.

In summary, we have shown that the expression of IL-22 is enhanced in infiltrating inflammatory cells and that expression of IL-22R1 and REG I $\alpha$ is concurrently enhanced in the inflamed epithelium in UC mucosa. In addition, we have clarified that IL-22 stimulation enhances REG I $\alpha$ expression by activating its gene promoter through the STAT3 pathway in vitro. Taken together, these data suggest that REG $I \alpha$ protein acts as a biological mediator for immune cell-derived IL-22 in the pathogenesis of UC.

Supplementary Information accompanies the paper on the Laboratory Investigation website (http://www.laboratoryinvestigation.org)

\section{ACKNOWLEDGEMENTS}

We thank Chiaki Matsuyama, Ayako Shimizu, Takako Ono, Midori Katayama, Atsuko Kikuchi, Sachiko Miyahara, and Nozomi Nagashima (Department of Surgical and Molecular Pathology, Dokkyo University School of Medicine, Tochigi, Japan) for their excellent technical and secretarial assistance. This work was supported in part by Grants-in-aid for Scientific Research 19790494 and 20590747 from the Ministry of Education, Culture, Sports, Science and Technology, Japan.

\section{DISCLOSURE/CONFLICT OF INTEREST}

The authors declare no conflict of interest.

1. Terazono $\mathrm{K}$, Yamamoto $\mathrm{H}$, Takasawa $\mathrm{S}$, et al. A novel gene activated in regenerating islets. J Biol Chem 1988;263:2111-2114.

2. Fukui $\mathrm{H}$, Franceschi $\mathrm{F}$, Penland RL, et al. Effects of Helicobacter pylori infection on the link between regenerating gene expression and serum gastrin levels in Mongolian gerbils. Lab Invest 2003;83: 1777-1786.

3. Fukui $\mathrm{H}$, Fujii S, Takeda J, et al. Expression of Reg $1 \alpha$ protein in human gastric cancers. Digestion 2004;69:177-184.

4. Fukui $H$, Kinoshita $Y$, Maekawa T, et al. Regenerating gene protein may mediate gastric mucosal proliferation induced by hypergastrinemia in rats. Gastroenterology 1998;115:1483-1493.

5. Sekikawa A, Fukui $H$, Fujii $S$, et al. Possible role of REG $1 \alpha$ protein in ulcerative colitis and colitic cancer. Gut 2005;54:1437-1444. 
6. Sekikawa A, Fukui $\mathrm{H}$, Fujii $\mathrm{S}$, et al. REG $1 \alpha$ protein may function as a trophic and/or anti-apoptotic factor in the development of gastric cancer. Gastroenterology 2005;128:642-653.

7. Dumoutier L, Louahed J, Renauld JC. Cloning and characterization of IL-10-related T cell-derived inducible factor (IL-TIF), a novel cytokine structurally related to IL-10 and inducible IL-9. J Immunol 2000;164: 1814-1819.

8. Liang SC, Tan XY, Luxenberg DP, et al. Interleukin (IL)-22 and IL-17 are coexpressed by Th17 cells and cooperatively enhance expression of antimicrobial peptides. J Exp Med 2006;203:2271-2279.

9. Wilson NJ, Boniface K, Chan JR, et al. Development, cytokine profile and function of human interleukin 17-producing helper T cells. Nat Immunol 2007;8:950-957.

10. Zheng $Y$, Danilenko $D M$, Valdez $P$, et al. Interleukin-22, a $T_{H} 17$ cytokine, mediates IL-23-induced dermal inflammation and acanthosis. Nature 2007;445:648-651.

11. Kleinschek MA, Boniface K, Sadekova S, et al. Circulating and gutresident human Th17 cells express CD161 and promote intestinal inflammation. J Exp Med 2009;206:525-534.

12. Zenewicz LA, Yancopoulos GD, Valenzuela DM, et al. Innate and adaptive interleukin-22 protects mice from inflammatory bowel disease. Immunity 2008;29:947-957.

13. Cella M, Fuchs A, Vermi W, et al. A human natural killer cell subset provides an innate source of IL-22 for mucosal immunity. Nature 2009;457:722-725.

14. Zheng $Y$, Valdez PA, Danilenko DM, et al. Interleukin-22 mediates early host defense against attaching and effacing bacterial pathogens. Nat Med 2008;14:282-289.

15. Sanos SL, Bui VL, Mortha A, et al. ROR $\gamma$ t and commensal microflora are required for the differentiation of mucosal interleukin 22-producing NKp46 ${ }^{+}$cells. Nat Immunol 2009;10:83-91.

16. Takatori $\mathrm{H}$, Kanno $\mathrm{Y}$, Watford WT, et al. Lymphoid tissue inducerlike cells are an innate source of IL-17 and IL-22. J Exp Med 2009; 206:35-41.

17. Dumoutier L, Roost EV, Colau D, et al. Human interleukin-10-related T cell-derived inducible factor: molecular cloning and functional characterization as an hepatocyte-stimulating factor. Proc Natl Acad Sci USA 2000;97:10133-10149.

18. Xie $M H$, Aggarwal $\mathrm{S}$, Ho WH, et al. Interleukin (IL)-22, a novel human cytokine that signals through the interferon receptor-related proteins CRF2-4 and IL-22R. J Biol Chem 2000;275:31335-31339.

19. Aggarwal $\mathrm{S}, \mathrm{Xie} \mathrm{MH}$, Maruoka $\mathrm{M}$, et al. Acinar cells of the pancreas are a target of interleukin-22. J Interferon Cytokine Res 2001;21:1047-1053.

20. Wolk K, Kunz S, Witte E, et al. IL-22 increases the innate immunity of tissue. Immunity 2004;21:241-254.

21. Andoh A, Zhang Z, Inatomi O, et al. Interleukin-22, a member of the IL10 subfamily, induces inflammatory responses in colonic subepithelial myofibroblasts. Gastroenterology 2005;129:969-984.

22. Wolk K, Witte E, Hoffmann U, et al. IL-22 induces lipopolysaccharidebinding protein in hepatocytes: a potential systemic role of IL-22 in Crohn's disease. J Immunol 2007;178:5973-5981.

23. Dieckgraefe BK, Stenson WF, korzenik JR, et al. Analysis of mucosal gene expression in inflammatory bowel disease by parallel oligonucleotide arrays. Physiol Genomics 2000;4:1-11.
24. Lawrance IC, Fiocchi C, Chakravarti S. Ulcerative colitis and Crohn's disease: distinctive gene expression profiles and novel susceptibility candidate genes. Hum Mol Genet 2001;10:445-456.

25. Kornbluth A, Sachar DB. Ulcerative colitis practice guidelines in adults (update): American college of gastroenterology, practice parameters committee. Am J Gastroenterol 2004;99:1371-1385.

26. Carter MJ, Lobo AJ, Travis SPL, et al. Guidelines for the management of inflammatory bowel disease in adults. Gut 2004;53(Suppl V):v1-v16.

27. Nanakin A, Fukui $\mathrm{H}$, Fujii $\mathrm{S}$, et al. Expression of the REG IV gene in ulcerative colitis. Lab Invest 2007:87:304-314.

28. Yoshitake N, Fukui $\mathrm{H}$, Yamagishi $\mathrm{H}$, et al. Expression of SDF-1 alpha and nuclear CXCR4 predicts lymph node metastasis in colorectal cancer. $\mathrm{Br}$ J Cancer 2008;98:1682-1689.

29. Monteleone G, Fina D, Caruso R, et al. New mediators of immunity and inflammatory bowel disease. Curr Opin Gastroenterol 2006:22:361-364.

30. Kanazawa S, Tsunoda T, Onuma E, et al. VEGF, basic-FGF, and TGF- in Crohn's disease and ulcerative colitis: a novel mechanism of chronic intestinal inflammation. Am J Gastroenterol 2001;96:822-828.

31. Nagalakshmi ML, Rascle $A$, Zurawski $S$, et al. Interleukin-22 activates STAT3 and induces IL-10 by colon epithelial cells. Int Immunopharmacol 2004;4:679-691.

32. Ziesche $E$, Bachmann $M$, Kleinert $H$, et al. The interleukin-22/STAT3 pathway potentiates expression of inducible nitric-oxide synthase in human colon carcinoma cells. J Biol Chem 2007;282:16006-16015.

33. Brand S, Beigel F, Olszak T, et al. IL-22 is increased in active Crohn's disease and promotes proinflammatory gene expression and intestinal epithelial cell migration. Am J Physiol Gastrointest Liver Physiol 2006;290:G827-G838.

34. Boniface K, Bernard FX, Garcia M, et al. IL-22 inhibits epidermal differentiation and induces proinflammatory gene expression and migration of human keratinocytes. J Immunol 2005;174:3695-3702.

35. Sugimoto K, Ogawa A, Mizoguchi E, et al. IL-22 ameliorates intestinal inflammation in a mouse model of ulcerative colitis. J Clin Invest 2008;118:534-544.

36. Andoh A, Shioya M, Nishida A, et al. Expression of IL-24, an activator of the JAK1/STAT3/SOCS3 cascade, is enhanced in inflammatory bowel disease. J Immunol 2009;183:687-695.

37. $\mathrm{Ng} \mathrm{J}$, Cantrell D. STAT3 is a serine kinase target in T lymphocytes. J Biol Chem 1997:272:24542-24549.

38. Lim CP, Cao X. Regulation of Stat3 activation by MEK kinase 1. J Biol Chem 2001;276:21004-21011.

39. Wolk K, Witte E, Wallace $E$, et al. IL-22 regulates the expression of genes responsible for antimicrobial defense, cellular differentiation, and mobility in keratinocytes: a potential role in psoriasis. Eur J Immunol 2006;36:1309-1323.

40. Radaeva S, Sun R, Pan H, et al. Interleukin 22 (IL-22) plays a protective role in T cell-mediated murine hepatitis: IL-22 is a survival factor for hepatocytes via STAT3 activation. Hepatology 2004;39: 1332-1342.

41. Ose $\mathrm{T}$, Kadowaki $\mathrm{Y}$, Fukuhara $\mathrm{H}$, et al. Reg I-knockout mice reveal its role in regulation of cell growth that is required in generation and maintenance of the villous structure of small intestine. Oncogene 2007;26:349-359. 